IDENTITY, IDEOLOGY, AND

THE FUtURE of JERUSALEM 



\section{IDENTITY, IDEOLOGY, AND The Future of Jerusalem}

David Hulme 


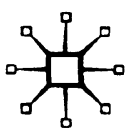

IDENTITY, IDEOLOGY, AND THE FUTURE OF JERUSALEM

(c) David Hulme, 2006.

Softcover reprint of the hardcover 1st edition 2006 978-1-4039-7424-2

All rights reserved. No part of this book may be used or reproduced in any manner whatsoever without written permission except in the case of brief quotations embodied in critical articles or reviews.

First published in 2006 by

PALGRAVE MACMILLAN'M

175 Fifth Avenue, New York, N.Y. 10010 and

Houndmills, Basingstoke, Hampshire, England RG21 6XS

Companies and representatives throughout the world.

PALGRAVE MACMILLAN is the global academic imprint of the Palgrave Macmillan division of St. Martin's Press, LLC and of Palgrave Macmillan Ltd. Macmillan ${ }^{\circledR}$ is a registered trademark in the United States, United Kingdom and other countries. Palgrave is a registered trademark in the European Union and other countries.

ISBN 978-1-349-73713-0 ISBN 978-1-137-06474-5 (eBook) DOI 10.1007/978-1-137-06474-5

Library of Congress Cataloging-in-Publication Data Identity, ideology, and the future of Jerusalem / by David Hulme. p. cm.

Includes bibliographical references and index.

1. Jerusalem-International status. 2. Nationalism-Palestine.

3. Group identity-Palestine. 4. Ideology-Political aspects-Palestine.

5. Statesmen-Palestine-Biography. 6. Jerusalem-Ethnic relations. I. Title.

DS109.95.H85 2005

956.94'4205-dc22

2005054530

A catalogue record for this book is available from the British Library.

Design by Newgen Imaging Systems ( $P$ ) Ltd., Chennai, India.

First edition: September 2006

1098765432

Transferred to Digital Printing 2011 


\section{CONTENTS}

List of Illustrations vii

Preface ix

Introduction 1

1 The Jerusalem Question $\quad 7$

2 Alternative Explanations 35

3 The Meaning and Significance of Jerusalem to the Jewish, Israeli, Arab, and Palestinian Peoples 51

4 Jewish and Israeli Personalities 67

5 Arab and Palestinian Personalities 127

$\begin{array}{ll}\text { Conclusions } & 179\end{array}$

$\begin{array}{ll}\text { Notes } & 191\end{array}$

Bibliography $\quad 207$

Index $\quad 227$ 



\section{List OF ILLUSTRATIONS}

\section{Tables}

1.1. Individual identity formation, life cycle stages, and psychosocial crises

2.1. Jerusalem's population by religion

\section{Maps}

2.1. Proposed minimal Israeli line of defense in the West Bank, 1967

2.2. Jerusalem-November $2003 \quad 42$

4.1. The Peel Commission Partition Plan, July 1937

4.2. The United Nations Partition Plan, $1947 \quad 90$ 



\section{Preface}

As might be expected in a work on one of the world's most perplexing political and humanitarian problems, the final product represents the culmination of many years of research and extensive travel. And as might be hoped, the author ought to undergo a significant change of perspective as the complexities of the area under study become better understood.

I began the project as many in the West would, with an already acquired admiration for the Jewish people's monumental achievement of statehood against what seemed all odds and in the terrible aftermath of the Nazi attempt at genocide. There is, of course, much to be said for the remarkable post-Shoah resurgence of this gifted people. Nevertheless, as my continuing research revealed, their success has come at a terrible price for the similarly gifted Palestinian people displaced during and following the two wars in 1948 and 1967. These massive disruptions of indigenous Palestinian life created the seemingly irresolvable Israeli-Palestinian conflict.

The specific subject matter of this work is but a fragment of the whole that makes up a very complex arena. Jerusalem is a microcosm of the conflict, and the Jerusalem Question rests heavily on all who labor to resolve the broader impasse. Without resolution on the issue of Jerusalem, its holy sites, sovereignty, and municipal government, there can be no peace. The just and equitable peace that all people of rationality and goodwill seek must come through honest and searching dialogue. As this study makes clear, a profound understanding of personal identity, its creation and its malleability, must play a central role in the critically needed realignment of the thinking of Israeli and Palestinian leaders and publics alike.

Experience has also taught me that many readers of the book's findings will struggle to steer a middle course. One well-informed recipient of an earlier version of the manuscript wrote that he agreed with me one hundred percent about the Israeli findings, but disagreed one hundred percent about the Palestinian ones. It was a striking confirmation of how difficult it is to get beyond established identity. He simply could not see the Other's needs. And therein lies the challenge and opportunity of the Jerusalem Question, when seen through the prism of identity and ideology. Read on with the 
caveat that you may find your own identity challenged, no matter which side of the conflict you occupy.

I would be remiss if I did not thank Laurie Brand, Anne Crigler, Michael Fry, Steven Lamy, and James Rosenau for their support, encouragement, and critical thinking during the process of research and writing. Duane Abler, Jeannette Anderson, and Gina Stepp were my indispensable helpers with cartography, word processing, and proofreading. I also want to thank Farideh Koohi-Kamali, David Pervin, Heather Van Dusen, and Elizabeth Sabo of Palgrave Macmillan for their encouragement and enthusiasm for the project, as well as Maran Elancheran and Bhuvana Venkatesh for their expert help in preparing the typescript for print. My two sons, their wives, and my daughter have had to withstand my frequent digressions into the latest findings, and I thank them for their patience.

By no means least, I thank my wonderful wife Deborah for her continuous support and cheerful spirit as she endured my "absent presence" during months of writing. This book is dedicated to her, and to two other very special people: my late wife Robin, who was there for the beginning, and our new granddaughter, Riley, who is here for the completion. It is for Deborah in gratitude, and for Robin and Riley - as for the Israelis and the Palestinians-in memory and in hope.

\section{A Note ON TRANSLITERATION}

Though Arabic can be transliterated in more than one way, some names have become best known in a particular form, which I have chosen to follow. But because of the possible variations, a number of inconsistencies will be apparent between the text, the notes, the bibliography, and other sources. Hence Yasser Arafat may appear as Yasir 'Arafat and Ahmad Quray' as Qurei, Korei, or Quri. In some cases, the 'ayn (') and/or hamza (') are retained (as in Abu Ala') and not in others (as in Edward Said, rather than Sa'id). 